\title{
PENGAJARAN KITAB TURATS MELAYU DI BRUNEI DARUSSALAM.
}

\author{
Harapandi Dahri \\ E=lomberhari@yahoo.co.id \\ Kolej Universiti Perguruan Ugama Bandar Sri Bagawan ,Brunai Darussalam
}

\begin{abstract}
This writing is aimed at discussing the important meaning of turath book in Brunei Darussalam literally as a heritage. While in acontemporary framework, turath is the richness of intellectual tradition treasury inherited by the former religious scholars (alqudama'). The research methodology is a library research. The result of the research indicates that turath book in Brunei is identical with yellow Book (kitabkuning) although in reality there is actually turath book in yellow. But this is not a big deal because what it meant in this writing is that turath book is the book of former religious scholars, whether it is yellow or not. Turath or more known as theyellow book as a group is often underestimated because it is considered outdated. But in reality, the content of the Turath and its relevancy with the religious understanding of Brunei nowadays are not fully understood. Yellow books are Arabic religious books or written in Arabic by salaf scholars and printed in yellow paper. Actually, the most proper called books as al-turathare the books that contain the treasury of Islamic civilization development creativity in the past. In the treasury there are things are very principles and cannot be ignored.Besides that, the treasury is also composed of the things that are open to criticism. We can ignore some of them because they are not relevant anymore. However,usul figh books, mushtalah al-hadits, nahwu-sharaf, tafsir knowledge, and tajwid are all principles, therefore we have to use those books. The conclusion of turath book studies in Brunei Darussalam is not limited to campuses but also taught in mosques in Brunei Darussalam. Book studies that are spread in mosques are limited to aqidah study, fiqh andtasawuf of ahlussunnahwaljama'ah by Imam al-Syafi'i mahzab as the official mahzab in Brunei Darussalam state..
\end{abstract}

Keys word :KitabTurats, Melayu, Brunei Darusslam

\section{Pendahuluan}

Kolej Universiti Pergunuan Ugama Seri Begawan sebagai salah satu Pengajian Tinggi di Negara Brunei Darussalam memiliki keunikan tersendiri iaitu dengan mengembangkan pengajian Kitab Turath bagi semua pelajar dan juga orang ramai. Kitab-kitab yang diajarkan di KUPU SB merupakan sebahagian kitab yang mengandungi nilai-nilai

keugamaan yang berasaskan kepada Ahlussunnah wa al-Jama'ah dan berfahaman mazhab al-Syafii. Kitab-kitab turath yang ada dan digunapakai ada yang menggunakan bahasa aseli kitab (Arab) dan ada yang berbahasa Melayu.

Bahasa Melayu sebagai bahasa rasmi negara sama sekali tidak dapat dipisahkan 
dengan tulisan Jawi. Kitab-kitab asas ugama juga adalah dalam bahasa Melayu dan ditulis dengan tulisan Jawi. Ugama Islam dan Bahasa Melayu adalah satu kesatuan yang menjadi asas kepada perkembangan dan kemantapan budaya. Ini memberi makna bahawa tulisan Jawi dan Kitab Turath adalah dua nilai yang menjadi asas kepada berdirinya bangsa dan budaya orang Brunei.

Di samping itu, al-Quran yang diturunkan dalam Bahasa Arab menjadi sumber Pengajian Islam dan tulisan Jawi. Ugama Islam, bangsa dan bahasa Melayu adalah kesatuan yang tidak terpisah dan memberikan satu makna bahawa tulisan Jawi adalah tulisan ugama dan tulisan nasional. Prinsip ini pemah dititahkan oleh KDYMM Paduka Seri Baginda Sultan dan Yang DiPertuan Negara Brunei Darussalam dalam Majis Pertandingan Membaca al-Quran Bahagian Dewasa Peringkat Kebangsaan Tahun 1991 pada 28 Jamadilakhir $1411 \mathrm{H}$ bersamaan 14 Januari $1991 \mathrm{M}$ :

"...Beta yakin, banyak hal-hal yang relevan untuk kita buat yang bersesuaian dengan rancangan ini, seperti memajukan dan mengembangkan lagi tulisan Jawi sebagai tulisan al-Quran, tulisan ugama, dan juga tulisan nasional.

Kita adalah tidak mahu untuk kehilangan tulisan Jawi, sebab inilah satu-satunya yang agung dan besar dari warisan yang masih tinggal yang boleh kita banggakan. Kehilangan tulisan ini akan banyak menjejaskan kepentingan-kepentingan kita, seperti pudamya semangat nasional dan binasanya ugama, kerana fungsi tulisan itu juga mendukung kedua-dua perkara tersebut..."

Dalam Titah yang lain sempena Majlis Konvokesyen Ketiga Kolej Universiti Perguruan Ugama Seri Begawan, pada 26 Muharram $1435 \mathrm{H}$ bersamaan 30 November 2013 M. Titah Kebawah Duli Yang Maha Mulia Paduka Seri Baginda Sultan Haji
Hassanal Bolkiah Mu'izzaddin Waddaulah Ibni Al-Marhum Sultan Haii Omar 'Ali Saifuddien Sa'adul Khairi Waddien, Sultan dan Yang DiPertuan Negara Brunei Darussalam:

"Beta berpendapat tulisan Jawi dan Pengajian Kitab Turath ini adalah perlu dipertahankan bahkan mustahak diperkasakan, kerana Jawi adalah merupakan identitii bangsa, sementara pengajian Kitab Turath pula adalah merupakan warisan ilmu Islam yang sangat berharga.Ke arah itu, sesuai dengan keunikan KUPU SB sebagai peneraju pendidikan Islam, maka beta melihat KUPU $S B$ adalah institusi yang paling sesuai untuk menawarkan atau mengendalikan programprogram akademik di bidang tulisan Jawi dan Kitab Turath sebagai sifatnya tunggak kecemerlangan Islam di negara ini".

Dalam upaya menjunjung Titah Kebawah Duli Yang Maha Mulia Paduka Seri Baginda Sultan Haji Hassanal Bolkiah Mu'izzaddin Waddaulah Ibni Al-Marhum Sultan Haji Omar 'Ali Saifuddien Sa'adul Khairi Waddien, Sultan dan Yang Di-Pertuan Negara Brunei Darussalam, maka KUPU SB sebagai satu-satunya pengajian Tinggi yang fokus terhadap kajian dan pengajaran Kitab Turath dan untuk memberikan pengetahuan dasar kepada seluruh pelajar, juga kepada orang ramai. Tulisan ini akan memberikan gambaran awal terkait dengan apa dan bagaimana proses pengajaran kitab turath yang dijalankan di Pengajian Tinggi Agama Islam di Negara Brunei Darussalam.

\section{Mengenal Kitab Turath}

\section{1) Apa kitab turath}

Sebelum kita meneruskan pembahasan mengenai dengan kitab Turath, maka perlu mengenai apa Kitab Turath dari segi bahasa mahupun istilah. Seperti kita ketahui bahawa Kitab Turath tersusun dari dua akar kata iaitu kitab dan turath. 
Kitab berasala dari kata arab " كi "يكتب- كتابا 'bererti telah menulis, sedang dan akan menulis dan hasil tulisan/karya yang dihasilkan. Secara istilah kitab dapat diartikan sebagai kumpulan tulisan para Ulama' yang mengandungi pelbagai informasi keilmuan, sama ada ilmu-ilmu yang berkaitan dengan aqidah, feqh, akhlak, al-Quran, al-Hadith, dan lain-lainnya.

Sedangkan Turath berasalah dari " الإرثر" yang peninggalan/warisan dari masa silam yang digunapakai oleh generasi berikutnya. Sedangkan secara istilah turath dapat dimaknai sebagai semua yang ditinggalkan oleh para pendahulu kita baik berupa benda-benda yang dapat dimanfaatkan seperti karya kitab/buku ataupun yang bersifat maknawiyah seperti khazanah pemikiran.

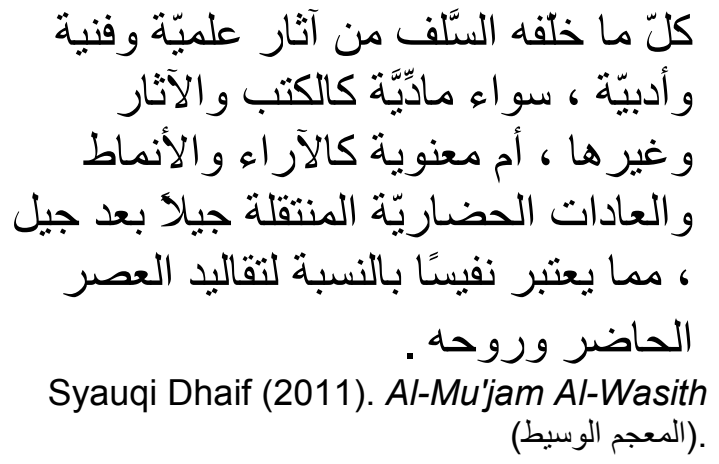

Turâth merupakan segala sesuatu yang sampai kepada kita dari masa lalu dalam peradaban yang dominan, sehingga merupakan masalah yang diwarisi sekaligus masalah penerima yang hadir dalam berbagai tingkatan Sementara pembaharuan merupakan penafsiran ulang atas tradisi sesuai dengan kebutuhan-kebutuhan zaman, karena yang lama mendahului yang baru. Turâth merupakan pijakan awal sebagai upaya pembaharuan dengan merubah tatanan sosial menuju kemodernan. Karena turâth merupakan bagian identitas suatu bangsa, maka ia menjadi tanggung jawab nasional. Meski demikian, bukan berarti bahwa seluruh identitas umat berada dalam turâth. Identitas juga terkait dengan kemodernan. Menurut Hasan Hanafí, jika insan muslim hanya terpaku pada turâth, berarti ia menjadi manusia tertutup yang hanya memiliki identitas semu. (Hasan Hanafí, 2002- 13.

Turâth merupakan sarana dan modemitas merupakan tujuan. Turâth dapat dijadikan alat bantu untuk mencari solusi alternatif terhadap berbagai probematika yang sedang dihadapi umat Islam. Turâth dapat ikut andil menghapus segala sesuatu yang dapat menghambat kemajuan. Turâth tidak memiliki arti berharga jika dibiarkan mati dalam sejarah, namun ia akan hidup dan dapat menjadi spint pembaharuan jika disikapi secara kritis. Dengan demikian, ia dapat menjadi sarana untuk merubah manusia sebagai subyek pembaharuan_(Hasan Hanafí, 1998-344).

Turâth dapat dibagi menjadi dua macam, iaitu turâth secara materi dan turâth non materi. Turâth materi berupa peninggalan masa lalu, seperti kitab dan manuskrip yang terdapat di berbagai perpustakaan Islam yang tersebar di selunuh dunia. Turâth seperti ini belakangan mendapatkan perhatian lebih dari berbagai pemikir Islam kontemporer. Banyak upaya untuk mengadakan revitalisasi turâth Islam dengan mencetak ulang buku peninggalan masa lalu tersebut, baik dilakukan tahqîq terlebih dahulu atau tidak.

Kerdua: turâth sebagai peninggalan sejarah yang berupa gambaran realita masa lalu. Maksudnya adalah bahwa berbagai buku dan manuskrip tersebut tidak datang dari ruang hampa. Spirit generasi terdahulu, baik dari fase pembentukan peradaban, perkembangan maupun kemunduran dan kehancuran suatu peradaban dapat dilihat dari turâth yang ditinggalkan. (Wahyudi, 2013). 
Kedua-dua macam turath tersebut dapat menjadi bahan kajian untuk melihat masa akan datang, kekuatan turath masa silam dapat menggambarkan kekuatan budaya yang ada pada masa itu. Kerana itu, kitab turath sebagai salah satu dari bentuk turath masa silam yang dapat mewujudkan pembaharuan dalam pelbagai pengetahuan perlu dijadikan rujukan sama ada yang masih berbentuk manuskrip ataukah yang sudah dimodenkan dalam bentuk kitab-kitab moden. Usaha ke arah sedemikian akan dilakukan secara berterusan di Kolej Universiti Perguruan Ugama Seri Begawan.

Melayu, Kata Melayu menurut para sarjana memberikan berbagai-bagi pendapat, antaranya:

1. Werndly melihat bahawa kata Melayu berasal daripada perkataan Melaju yang bermakna cepat, deras dan tangkas. Maknanya orang Melayu itu bersifat tangkas dan cerdas, segala tindak tanduk mereka cepat dan deras.

2. Darus Ahmad mengatakan bahawa kata Melayu diambil sempena nama sejenis pohon yang harum baunya iaitu pohon gaharu. Orang India pada masa silam memanggil tanah Melayu sebagai Negeri Gaharu.

3. I-Tsing dalam tulisannya sejak abad ketujuh Masihi telah menyebut perkataan Mo-lo-yeu atau Mo-loyou.

Jadi Kitab Turath Melayu Islam dapat diertikan sebagai kitab tulisan tangan para Ualama Melayu ataupun cetakan yang memakai bahasa Melayu Lama (ejaan atau tulisan Jawi) sebagai dasar tulisannya.

\section{Penulisan Kitab Turath Melayu}

Ada beberapa tulisan yang berkembang di alam Melayu seperti tulisan Rencong, yang lazim digunakan di Sumatera Selatan, daerah Bengkulu dan Palembang sebelah hulu, tulisan Kawi berkembang di Jawa, tulisan Lempong, Batak, Bugis dan Makasar. Namun setelah Islam berkembang di alam Melayu, maka tulisan Jawi yang diambil daripada tulisan al-Qur'an telahpun mampu menjadi alat yang menyatukan kelompok bahasabahasa tersebut, sehingga dengan tulisan Jawi kebersatuan antara masyarakat alam Melayu pun tercipta dengan baik.

Akhirnya dengan berkembang majunya Islam di alam Melayu, maka terdapat tulisantulisan para pujangga, ulama' sasterawan dalam berbagai-bagai bidang kajian seperti sastera, falsafah, metafizik dan juga teologi rasional. Bahkan penterjemahan al-Qur'an yang pertama dalam bahasa Melayu telah diselenggarakan beserta syarahannya yang berdasarkan Tafsir al-Baidhawi, dan terjemahan lain beserta syarahannya dan kerja-kerja asli dalam bidang falsafah, tasawur, dan ilmu kalam semuanya menggunakan tulisan Jawi.

Menurut Syed Muhammad Naguib AlAttas bahawa nilai utama yang terdapat dalam sejarah bahasa Melayu yang disebabkan oleh Islam berpunca pada penyatuan kelompok bahasa-bahasa yang dapat digelar Melayu supaya menjadi satu bahasa bangsa Melayu. Ini telah tercapai dengan menyatu paduan kelompok bahasa-bahasa itu melalui alat suatu tulisan yang sama. Tulisan ini kita ketahui sebagai Tulisan Jawi yang sudah hampir seribu tahun menjadi tulisan bahasa Melayu. (Pehin Jawatan Luar Pekerma Raja dato Seri Utama DR Ustaz Haji MD. Zain Haji Serudin. 1998, 92-94).

Kitab Turath Melayu ditulis oleh berbagai-bagai Ulama yang memahami dan menguasai ilmu-ilmu agama Islam dalam ragam disiplin keilmuan seperti bidang aqidah, syar'ah, tasawuf, falsafah, al-Qur'an, alHadith. Pada awal penulisan kitab-kitab Turath 
Melayu di Masjid-masjid, Surau-surau, Pondok-pondok Pesantren dan di tempattempat kediaman para ulama' itu sendiri. Tempat-tempat penulisan dan penyimpanan manuscript dalam ilmu Filologi ialah Scriptorium. (tempat untuk menulis", biasanya digunakan untuk menujuk kepada sebuah bilik di Eropah zaman pertengahan dikhaskan untuk penyalinan naskah oleh monastik).

Ada beberapa cara yang dilakukan ulama dalam menulis Kitab-kitab Turath Melayu, antaranya menulis sendiri tanpa bantuan seorangpun, cara inilah yang paling banyak dilakukan. Cara berikutnya ialah ulama meminta para santrinya untuk menulis kitab-kitab yang dibacakan oleh para ulama' dan cara terakhir para santri menulis secara sendiri atas dasar pengetahuan yang telah diperoleh melalui para ulama' kemudian disandarkan kepada ulama bersangkutan.

\section{Keunikan kitab turath}

la Menulis Sementara Aku Tidak. Abu Hurairah radhiallahu anhu berkata (tidak ada satupun sahabat Nabi Muhammad Sallallahu 'Alaihi wa sallam yang lebih banyak haditsnya daripada aku, kecuali Abdullah bin Amr, karena sesungguhnya ia menulis sementara aku tidak menulis). (Bukhari:113)

Tulislah Walau Di Dinding: As Sya'by rahimahullah berkata; bila engkau mendengar sesuatu maka tulislah walaupun di dinding). (Abu Khaitsamah dalam Al-IImu, No 146).

Segera la Tulis Karena Takut Hilang: Al Humaidy rahimahullah berkata (aku pemah pergi bersama Syafi' ke Mesir, la tinggal di atas sementara aku tinggal di tengah, suatu saat aku keluar malam hari dan aku melihat ia menyalakan lentera, maka aku pun berteriak kepadanya, ia mendengar suaraku lalu ia berkata: naiklah, maka aku naik temyata ada kertas dan tinta, akupun berkata: apa yang engkau lakukan wahai Abu Abdillah? la berkata: terpikirkan olehku makna suatu hadits atau suatu masalah ilmiah dan aku takut akan hilang dariku maka aku menyalakan lentera dan menulisnya). (Al-Imam Ibn Hajar alAtsqalani. $1301 \mathrm{H}-43$ ).

Banyak Sekali Kitab Yang Telah la Salin Dengan Tangannya: Adalah Muhammad bin Ahmad bin Qudamah rahimahullah telah menulis ulang banyak sekali kitab dengan tanganya sendiri diantaranya: Al Mughny, Tafsir Al Baghawy, Hilyatul Auliyaa, Al Ibaanah milik Ibnu Batthah, dan banyak juga mushaf AI Qur'an yang ia salin. (Ibnu Rajab alHanbali.1425/2005).

Bila Tidak Ditulis Maka Sia-Sia: Ma'mar rahimahullah berkata (aku meriwayatkan beberapa hadits kepada Yahya bin Abi Katsir, lalu ia berkata: tuliskan untukku hadits ini dan hadits ini, maka aku berkata: aku tidak suka menulis ilmu, ia berkata: tulislah karena sesungguhnya bila engkau tidak menulis maka engkau telah berbuat sia - sia) atau ia berkata (.....engkau akan lemah). (Abdurrazaq dalam Al-Mushannaf, No. 20488).

Jangan Pergi Sampai Aku Menulisnya: Abdurrahman bin Mahdy rahimahullah berkata (aku pemah berjalan bersama Abdullah bin Mubarak lalu aku ingatkan ia tentang suatu hadits, maka ia berkata: jangan pergi sampai aku menulisnya). (Abu Nuaim alAshbahani.(1988).9/3)

la Menulis Apapun Yang la Dengar. Abu Az-Zinaad rahimahullah berkata (dahulu kami hanya menulis halal dan haram saja, sementara Ibnu Syihab menulis apapun yang ia dengar, maka tatkala hal-hal tersebut diperlukan, akupun tahu bahwa Ibnu Syihab adalah orang yang paling berilmu). (Imam Syamss al-Din az-Zahabi. (2006) 5/332)

Tanpa Tulisan Tak Akan dapat Hafal: Abu Shalih Al Faraa' rahimahullah berkata (aku bertanya kepada Ibnul Mubarak tentang pentingnya menulis ilmu, maka ia berkata: kalau bukan karena tulisan tentulah 
kita tak akan dapat menhafal). (Imam al-Din az-Zahabi. (2006). 8/409)

Menulis Sambil Berdir: Abu Fadhl bin Nabhan Al Adiib rahimahullah berkata (suatu ketika aku melihat Abul Alaa di dalam salah satu masjid diantara masjid-masjid Baghdad, la sedang menulis sambil bediri diatas kedua kakinya, karena lentera-lentara di tempat itu sangat tinggi). (Ibnu Rajab al-Hanbali. $(1425 / 2005) .1 / 326)$

Seakan Setiap Hari Menulis Enam Puluh lembar Lebih: Imam Abu Ja'far Muhammad bin Jarir At Thabary rahimahullah dapat dibilang keajaiban bagi umat islam. la telah menulis banyak kitab dalam berbagai bidang ilmu, seandainya jumlah seluruh kertas yang telah ia tulis dibagi dengan jumlah umurnya, maka seakan setiap hari beliau menulis enam puluh lembar lebih. Suatu ketika ia menyuruh murid-muridnya untuk menulis tarikh islam atau tafsir, lalu beliau meminta disediakan tiga puluh ribu lembar kertas. Maka para muridnya berkata (pekerjaan ini akan memerlukan waktu yang sangat panjang) maka ia berkata kepada mereka (Allahu Akbar, telah matikah semangat kalian, sediakan tiga puluh ribu lembar kertas). (Imam al-Din az-Zahabi. (1374). 2/712)

Dari Pelbagai ucapan para ilmuan tersebut menunjukkan betapa pentingnya budaya tulis-menulis. Di alam Melayu kedatangan Islam merupakan titik peralihan sejarah rantau ini. la bukan sahaja mengubah kepercayaan orang Melayu dari menyembah cakerawala dan patung kepada menyembah Allah Yang Maha Esa, tetapi juga mengubah pikiran dan pandangan hidup mereka serta membawa budaya ilmu yang dibawa Islam kerantau ini ialah budaya menulis dan membaca. Budaya menulis dan membaca memang sudah menjadi minat dan kegemaran para ulama sejak dahulu hingga sekarang. Kegemaran dan minat ini timbul hasil inspirasi ajaran agama Islam itu sendiri supaya ilmu yang ditulis dapat dibaca dan seterusnya disebar dan dimanfaatkan oleh masyarakat.

Ayat al-Qur'an yang pertama diturunkan Allah kepada Nabi Muhammad Sallallahu 'Alaihi Wasallam di dahului oleh kalimah "iqra". Dalam konteks ini Allah berfirman dalam Surat al-'Alaq/96:1-5 :

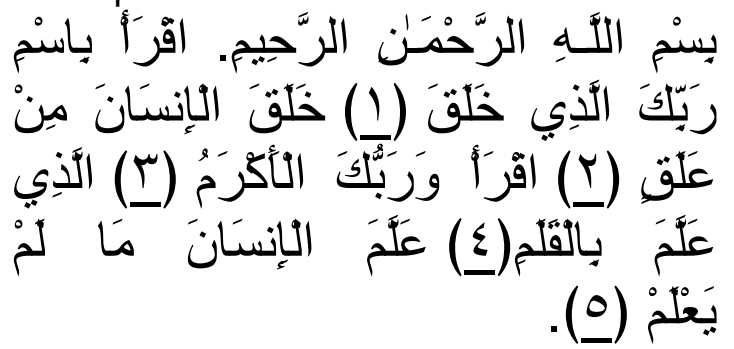

$\begin{array}{ccr}\text { Maksudnya: } & \text { Bacalah dengan } \\ \text { (menyebut) nama Tuhanmu Yang }\end{array}$ menciptakan, Dia telah menciptakan manusia dari segumpal darah. Bacalah, dan Tuhanmulah Yang Maha Pemurah, Yang mengajar (manusia) dengan perantaran kalam, Dia mengajar kepada manusia apa yang tidak diketahuinya.

Ayat di atas menjelaskan bahawa budaya membaca adalah asas dalam pendidikan Islam. Dengan sebab itu dari awalawal lagi al-Qur'an menitikberatkan aspek pembacaan dan penulisan. Perkataan "iqra" di dalam ayat ini membawa maksud "membaca", "belajar" dan "mengkaji". (Mahyuddin Hj Yahya (2001).1-2).

Konsep "pengabdian kepada Allah" merupakan ciri kedua yang disebutkan dalam ayat "Dengan nama Tuhanmu". Ini bermakna bahawa setiap kegiatan pembacaan, penulisan dan pengkajian mestilah dilakukan kerana untuk mendapatkan keredaan Allah Ta'ala. Faktor kebahasaan merupakan ciri berikutnya, al-Qur'an diturunkan dalam bahasa Arab yang mengandungi unsur l'jaz, sebab itulah ia menjadi bahasa ilmu dan tamadun. Para ilmuan Islam masa silam 
termasuk orang Parsi, Turki, India dan Melayu telah mempelajari dan menulis dengan menggunakan bahasa Arab sebagai abahasa ilmu, khususnya ilmu-ilmu Islam.

Ketiga-tiga ciri yang disebutkan di atas merupakan asas atau frame work kepada sejarah perkembangan keilmuan Islam di Nusantara. Berbekalkan semangat dan ciri-ciri tersebutlah maka pena para ulama berselang paling dan idea-idea mereka seolah-olah terus mengalir di hujung pena masing-masing. Sejak itu ratusan ribu karya/kitab agama dihasilkan oleh ulama dari Asia Barat dan Asia Timur.

Budaya menulis dan berkarya ini diikuti oleh para ulama Melayu di Nusantara sejak mereka mengenali Islam hinggalah ke hari ini. Pihak pemerintah sama ada di Perlak, Samudera Pasai, Acheh, Brunei, Malaka, Riau dan negeri-negeri lain di kawasan Nusantara sentiasa memberi galakan dan kemudahan kepada para ulama menulis dan menyebarkan ilmu agama kepada masyarakat.

Pada generasai masa kini budaya menulis tidaklah hilang, bahkan kini semakin banyak karya-karya dalam bentuk buku, majalah, koran, tabloid dan media-media sosial lainnya. Kesemua itu bermattamtkan penyebaran idea kepada masyarakat. Buku adalah jendela dunia dan sahabat yang tidak pernah membohongi kita. Melalui buku kita boleh melihat apapun yang pernah sedang dan yang akan terjadi. Buku merupakan unsur penting dalam melihat keperibadian bangsa dan ketemadunan umat.

Dalam catatan sejarah Negara Brunei Darussalam adalah negara yang memiliki kerajaan yang kuat, besar, kaya dan rakyat dan penduduknya hidup aman dan bersatu padu. Oleh karena itulah terkenal dengan "Darussalam" yang bererti aman dan makmur. Pada awalnya Negara ini bemama Negara Melayu Beraja, namun setelah Islam berkembang maka ia dikenali sebagai Negara Melayu Islam Beraja (MIB).

Kitab turath sebagai sebuah karya para ulama terdahulu memiliki keunikan tersendiri bila dibandingkan dengan karya-karya para ilmuan masa kini. Keunikan-keunikan tersebut dapat dilihat dari pelbagai aspek seperti aspek penulis, aspek kitab turath dan dari aspek isi tulisan.

\section{1) Unik dari sisi penulis}

Jika kita bandingkan hasil tarbiyyah (pendidikan) generasai salaf (terdahulu) dengan generasi khalaf (kemudian), terlihat sekali perbezaannya. Generasi salaf, walaupun ilmunya yang ditandai dengan tanpa gelar memiliki kharisma dan semangat ibadah yang lebih kuat dan jika ia mengajarkan ilmunya dengan mudah dapat dicerna dan diamalkan dalam kehidupan nyata, sementara generasi khalaf (kemudian), ilmu dan gelar sudah sampai kederjah maksimal, namun ibadah dan kharisma ilmu tidak tampak pada dirinya. Semua ini disebabkan oleh beberapa faktor.

Pertama; Keikhlasan dalam berkarya mahupun mengajarkan ilmunya. Ikhlas iaitu melakukan sesuatu hanya untuk mencari ridha Allah Subhanahu Wa Ta'ala, tidak memiliki tujuan lain selain Allah. keikhlasan juga mengandung makna memumikan dalam hati terhadap kitab yang dituliskannya hanya untuk mendapatkan keridhaan Allah Subhanahu Wa Ta'ala. Kisah yang sangat populer dalam keikhlasan menulis kitab seperti kisah Imam Ibnu Ruslan, saat menulis kitab Zubad. (Ahmad bin Ruslan. (1404H/1984)).

"Imam Ibnu Ruslan menyelesaikan penulisan kitab Zubad di atas sebuah kapal yang berlayar di laut lepas. Belliau sebagai penumpang kapal bersama banyak orang. $D i$ saat orang lain tidur, makan dan minum, beliau sendirian tidak perduli dengan ramainya orang, beliau sibuk menyelesaikan bayt-bayt syairsyair dalam ilmu fegh.Saat kitab Zubad telah selesai ditulis, Imam Ibnu Ruslan mengikatkan 
batu di bagian atas dan bawah kitab tersebut. Beliau ingin melemparkan kitabnya ke laut lepas, Orang-orang yang melihat kejadian tersebut berusaha mencegahnya agar dijaga dan dipelihara tidak dilemparkan ke laut. Namun, usaha mereka untuk mencegah Imam Ibnu Ruslan tidak berhasil, sambil berkata beliau melemparha kitabnya ke dalam laut;"Biarkanlah. Jika kitab yang aku tulis ini benar-benar karena mengharap redha Allah, air laut tidak akan mampu merosaknya. Imam Ibnu Ruslan sangat yakin dan kuat keimanannya terhadap kebenaran fiman Allah Subhanahu Wa ta'ala. Maksudnya: "Segala sesuatu yang ada di dunia ini akan hancur, kecuali wajah Allah Azza wajalla".

Sebagian ahli tafsir mengertikan ayat tersebut dengan; "segala sesuatu yang ada di dunia ini akan hancur binasa kecuali pekerjaan yang diniatkan ikhlas karena Allah". Disebabkan keikhlasan pengarangnya, ombak berhasil membawa kitab tersebut ke tepi laut. Di tempat tersebut ada banyak nelayan mencari ikan, dan atas iradat Allah Azza wajalla kitab tersebut masuk ke dalam jaring ikan para nelayan yang ada di pinggir pantai. Nelayan yang nenemukan kitab tersebut pergi membawa dan memberikannya kepada salah seorang ulama di daerah itu. Sang Ulama'pun membaca dan menelaah isi kitab tersebut dan merasa takjub dengan rahsia yang terkandung di dalamnya.

Halaman demi halaman ulama' sang ulama meneliti dan menelaah, semakin terkagum dengan keindahan susunan dan kualiti kitab yang beraliran madzhab Syafi'i tersebut. Kemudian Ulama tersebut memerintahkan kepada murid-muridnya untuk menulis kembali dan memperbanyak serta menyebarluaskannya di kalangan masyarakat akademik.Dalam salah satu bayt syair yang terdapat dalam kitab Zubad Imam Ibnu Ruslan;

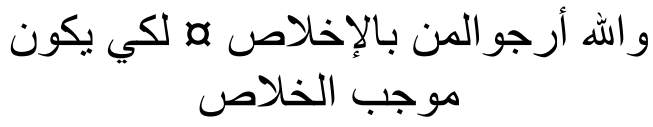

Artinya:" Ya Allah aku berharap siapa saja yang bekerja dengan keikhlasan agar mereka mendapatkan kesuksesan".

Kedua; Selalu memelihara kesucian; tradisi ulama salaf dalam semua kehidupan mereka, utamanya dalam menulis karya kitab selalu berada dalam kesucian (berwudhu), jika wudhu'nya batal, maka dengan segera mengambil wudhu' kembali. Tidak ada satu katapun yang mereka tulis tanpa berwudhu'. Bagi mereka ilmu itu adalah cahya dan cahya tidak akan dapat masuk kedalam tubuh dan hati manusia yang tidak bersih. Berwudhu merupakan simbol kebersihan jiwa dan juga raga, maka ilmu dengan mudah dapat masuk dan juga pikiran yang dihasilkannya adalah ilmu yang memberikan keberkatan. Jika seseorang berada dalam keadaan suci, berarti ai dekat dengan Allah. Karena Allah akan dekat dan cinta kepada orangorang yang berada dalam keadaan suci.

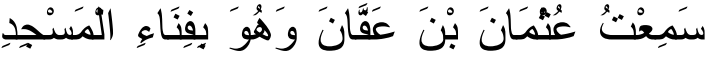

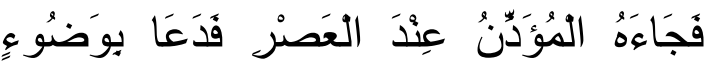

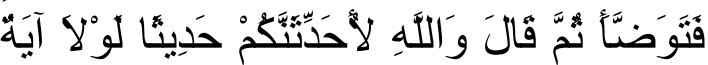

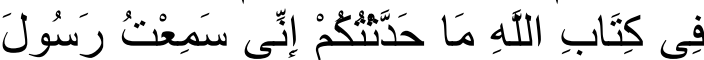

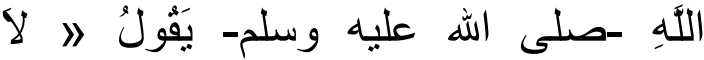

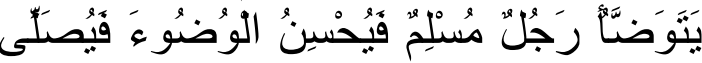

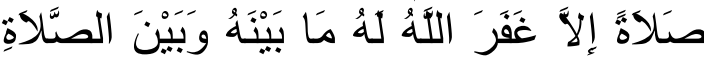
الَّنِى نَلَّبهَا.

Maksudnya: Aku mendengar Utsman bin Affan radhiyallahu'anhu ketika dia berada di halaman masjid kemudian datang seorang mu'adzin menjelang waktu Ashar tiba. Maka Utsman meminta diambilkan air wudhu, lalu dia berwudhu. Setelah itu dia berkata, "Demi Allah, sungguh aku akan menceritakan kepada kalian sebuah hadits. Kalaulah bukan karena suatu ayat di dalam Kitabullah niscaya aku tidak akan menuturkannya kepada kalian. Aku mendengar Rasulullah shallallahu 'alaihi wa sallam bersabda, 'Tidaklah seorang muslim berwudhu dan membaguskan wudhunya kemudian mengerjakan sholat melainkan Allah akan mengampuni dosa-dosanya 
sejak saat itu sampai sholat yang berikutnya." (HR. Muslim dalam Kitab at-Thaharah)

Ketiga; Sembahyang sunnat sebelum menulis; kebiasaan para ulama salaf sebelum menulis karyanya ialah bermunajat diawali dengan sembahyang sunnat. Sembahyang sebagai media berkomunikasi dengan Allah pemilik ilmu yang sebenamya, ilmu sebagai cahya akan dapat dengan mudah masuk ke dalam qalbu seseorang apabila selalu memelihara hubungan baik dengan pemilik ilmu. Sembahyang yang di dalamnya berisi doa dijalankan ulama salaf sebagai pembuka (miftah) dalam berkarya.

\section{2) Naskah kitab}

Bagi kebanyakan orang, kitab turath, mungkin sangat tidak menarik dan bahkan cendrung "menjijikkan", karena naskah kitab turath apalagi yang masih berwujud manuskrip (al-makhthuthat), selain kertas yang sudah rosak, tulisan yang tidak jelas, penulis dan tahun ditulisnya yang masih misteri dan pelbagai hal yang susah untuk dapat dipahami. Namun, bagi sebagian orang, kitab turath ibarat mencari mutiara di lautan yang sangat dalam, banyak halangan dan rintangan yang mesti dilalui, namun semakin dalam pencarian mutiaranya semakin terasa nikmat dan mengasyikkan.

\section{a) Cover Judul}

Dari mulai cover judul kitab turath sudah memberikan penegasan bahawa kitab-kitab ini tidak sama dengan buku-buku dan kitab moden lainnya. Cover judul hanya bertuliskan judul kitab tanpa nama, tahun dan tempat terbit atau bahkan untuk menjelaskan siapa penulis kitab, pembaca harus mencari dan membaca isi kitab secara teliti, kerana nama penulis tertera di bagian dalam depan ataupun belakang sebagai kolofon ${ }^{1}$ sebuah kitab.

\footnotetext{
${ }^{1}$ Salah satu penelitian pada bidang kodikologi ini adalah pegkajian mengenai kolofon. Kolofon merupakan penjelasan atau keterangan yang diberikan oleh pengarang atau penyalin yang basanya
}

Pesan yang tertuang dalam cover judul yang tidak menuliskan nama penulis, tahun dan tempat penulis ialah agar tidak menjadi riya' atau dalam bahasa mafhum mukhalafahnya agar selalu menjaga keikhlasan dalam berkarya.

lafazd basmalah ini pada kitab-kitab turath selalu menjadi kata pembuka, dan tidak jarang lafazd ini ditulis dalam bentuk khot yang lebih besar dan menarik ditambahkan dengan ornamen-ornamen sederhana. Kalimat basmalah ini menjadi kata pembuka dari semua kitab turath sebagai bukti para ulama salaf, tidak sekedar menulis kitab, melainkan juga berdakwah (mengajak) para pembaca kitab untuk selalu menjadikan basmalah sebagai miftah al-kalam wa al-kitabah.

Penulisan Al-Qur'an diawali dengan basmalah. Hal itu telah ditegaskan tidak hanya oleh seorang ulama, di antara mereka adalah Al Qurthuby yarhamuhullah di dalam tafsirnya. Beliau menyebutkan bahawa para sahabat radhiyallahu 'anhum telah bersepakat menjadikan basmalah tertulis sebagai ayat permulaan dalam Al-Qur'an, inilah kesepakatan mereka yang menjadi abadi -semoga Allah meridhai mereka- dan Al Hafizh Ibnu Hajar yarhamuhullah pun menyebutkan pernyataan serupa di dalam kitab Fathul Baari. (Solih Muhmmad bin al-Asmary. (1424). 9)

Nabi shallallahu 'alaihi wa sallam apabila menulis surat memulai dengan bismillaahirrahmaanirrahiim. Di dalam Kitab Bad'ul Wahyi Imam Bukhari menyebutkanhadits: "Bismillahirrahmaa

menjelaskan tempat dan waktu awal atau akhir penulisan atau juga keterangan-keterangan yang lainnya. Kolofon biasanya terletak di akhir naskah, namun sering juga dijumpai di awal naskah. 
nirrahiim min Muhammadin 'Abdillah wa Rasuulihi ila Hiraqla 'Azhiimir Ruum..." (Shahih Bukhari No.7, Shahih Muslim No.1773). Rasulullah Sallallahu 'Alaihi Wa Sallam bersabda; كل أمر ذي بال لا يبدأ فيه بسم الله الرحمن

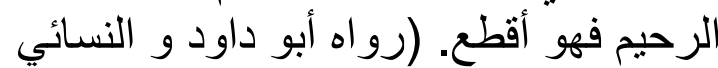
و إبن ماجة و إين حبان عن أبي هريرة) Maksudnya: Setiap amal (perbuatan) yang tidak di dahului (tidak dibaca di dalamnya) bismillahirrahmanirrahim, maka akan terputus (tidak akan memperolehi keberkatan)."

Pesan dari hadith tersebut ialah, semua aktiviti yang kita lakukan mesti diawali dengan membaca basmalah. Hadith inilah yang dijadikan dasar oleh para ulama salaf dalam menulis karyakarya mereka sehingga tidak pernah melupakan menulis basmalah di awal kitabnya.

\section{b) Substansi}

Sisi keunikan lain dari kitab turath ialah dari isi kandungan kitab. Dalam satu kitab turath terkadang mengandung dua atau lebih kitab yang berbeda, yang satu mengenai aqidah dan yang lainnya membincangkan feqh, yang satu mengenai tasawwuf yang lainnya membicangkan aqidah. Antara kitab-kitab yang terdapat pelbagai kitab di dalamnya ialah;

1)

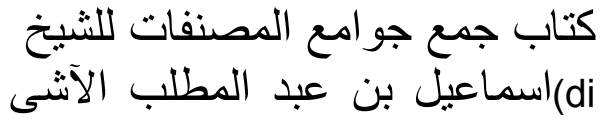
Aceh kitab ini dikenal dengan nama "Kitab Delapan" kerana di dalamnya tergabung 8 buah kitab (Aqidah, Feqh dan Tasawwuf). Kitab-kitab tersebut ialah; Kitab Hidayat al-Awam karya al-Syeikh Faqih Jalal al-Din al-'Asyi, Kitab
Faraid al-Qur'an karya, Kitab Kasyf al-Kiram karya al-Syeikh Muhammad Zain ibn Faqih Jalal al-Din al-'Asyi, Kitab Talkhis alFalahFi Bayan ahkam al-Thalaq wa al-Nikah karya al-Syeikh Muhammad Zain ibn Faqih Jalal al-Din al-'Asyi, Kitab Syifa' alQulub karya al-Syeikh Nur al-Din al-Raniri, Kitab al-Mawaiz alBadi'ah karya al-Syeikh 'Abdul Rauf al-Fanshuri al-'Asyi, Kitab Dawaul Qulub karya al-Syeikh Ahmad bin Khatib Langgien Al'Asyi dan Kitab I'lam al-Muttaqin Karya al-Syeikh Jamaluddin ibn Syaikh Abdullah

2) كتاب الدر الثمين di dalam kitab ini tergabung dua buah kitab), kedua-dua buah kitab ini membincangkan masalah aqidah. Kitab al-Durr al-Thamin karya al-Syeikh Daud ibn 'Abdullah al-Fatani, kitab ini membincangkan aqidah secara menyeluruh, kitab ini merupakan syarh dari kitab Matn Umm albarahin karya al-Imam Abi 'Abdillah Muhammad ibn Yusuf al-Sanusi al-Husna dan Kitab Dhiya' al-Murid fi Ma'rifat Kalimat al-Tauhid karya al-Syeikh Daud ibn 'Abdullah al-Fatani. Kitab ini berada pada tepi atau pinggir kitab al-Durr al-Thamin dan khusus membincangkan kalimat

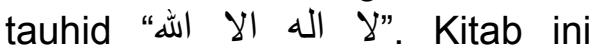
hanya berisi empat pasal utama dan satu pasal al-ikhtitam (penutup). Makna kalimat " لا له "الا اله sebagai pasal pertama, syarat membaca kalimat " لا اله الا اله adalah pasal kedua, adab 
membaca kalimat “له اله اله اله "ل sebagai pasal ketiga dan fadhail membaca kalimat "له اله اله اله sebagai pasal keempat dalam kitab ini. Pasal alikhtitammengandung bahasan masalah fadhilat mengajar dan menuntut ilmu.

3) كتاب تنبيه الغافلين(di dalam kitab karya al-Syeikh al-Hajj 'Abdullah ibn al-Mukminin al-Syafi'i, ini terdapat dua buah kitab. Kitab Tanbih al-Ghafilin merupakan kitab yang mengumpulkan beberapa hadith mengenai peringatan kepada orang awam terhadap dahsyatnya hari kiyamat. Kitab ini terdiri dari 12 bab dari halaman 1-22. Dan mulai dari halaman 22-35 kitab Ins al-Muttaqin Lillahi Rabbil 'Alamin karya al-Syeikh Husain ibn Muhammad. Kitab yang kedua ini membincangkan masalah ilmu tasawwuf yang terdiri dari lima bab. Bab pertama membincangkan masalah lalai dan fikir (sedar), kedua mengemukakan masalah ilmu dan Jahil, ketiga menjelaskan masalah aqal (cerdas) dan Khobal (gila), keempat menegaskan masalah faqir dan kaya dan kelima membahas masalah al-tawakkal dan al-Hirs (terjaga).

4) (di dalam kitab ini terdapat dua buah kitab. Kedua-dua buah kitab ini merupakan karya al-Syeikh Daud ibn 'Abdullah al-Fatani). Kitab Munyah al-Mushalli adalah kitab yang membincangkan masalah sembahyang secara spiritual. Kitab ini terdiri dari 37 tujuh muka surat, mulai dari muqaddimah hingga al-Ikhtitam. Kitab Munyah al-Mushalli merupakan karya alSyeikh yang disusun di Makkah al-Mukarramah pada waktu Dhuha iaitu hari selasa, tarikh 15 bulan Zulhijjah 1242 Hijriyyah. Kitab yang kedua ialah kitab alBahjat al-Mardhiyyah. Kitab ini berbicara mengenai masalahmasalah makmum dan imam. Kitab ini selesai ditulis oleh alSyeikh di Makkah al-Mukarramah pada waktu Ashr, hari selasa bulan Syawwal 1259 Hijriyyah.

5) كتاب سراج الهدى)(di dalam kitab ini terdapat dua buah naskah kitab yang berbeza, pertama kitab Sirajul Huda syarh atas matn Umm al-Barahin karya alSyeikh Muhammad Zainuddin ibn Muhammad Badawi al-Sambawi dan kedua kitab 'Athiyyat alRahman karya al-Syeikh Muhammad Azhari ibn 'Abdullah al-Palembani).Kitab Sirajul Huda karya al-Syeikh Muhammad Zainuddin ibn Muhammad Badawi al-Sambawi berisi aqidah ahl al-Taqwa (ahl Sunnah wa alJama'ah) sebagai syarh dari kitab Matn Umm al-Barahin alimam al-Sanusi.Kitab 'Athiyyat alRahman karya al-Syeikh Muhammad Azhari ibn 'Abdullah al-Palembani, berada satu kitab dengan kitab Siraj al-Huda. Kitab ini lebih fokus iaitu membahas masalah Qawaid (rukun) al-Iman. Menurut penulisnya, kitab ini ditulis setelah berdiskusi dengan teman-temannya di Makkah al- 
Mukarramah terkait kitab Matn Umm al-Barahin pada tahun $1259 \mathrm{H}$. Kitab ini merupakan ta'liqat (komentar) terhadap Matn Umm al-Barahin khususnya pada bagian al-Qudrah, al-Iradah dan al-Kalam.

6) كتاب منهاج السلام)di dalam kitab ini terdapat dua buah kita iaitu Kitab Minhaj al-Salam karya alSyeikh Muhammad Zainuddin ibn Muhammad Badawi al-Sambawi dan kitab Muqaranah sembahyang karya alSyeikhlsmail ibn 'Abdullah alKholidi).Kitab Minhaj al-Salam karya al-Syeikh Muhammad Zainuddin ibn Muhammad Badawi al-Sambawi berisi perincian masalah-masalah yang bergantung dengan keimanan dan keislaman. Kitab ini selesai di tashih oleh al-Syeikh 'Abdullah ibn Ibrahim langkir al-Qadhi dan diterbitkan pada penerbit Mushtafa al-Baby al-Halaby di Mesir bulan Syawwal tahun 1345. Kitab ini memiliki ketebalan 44 halaman sahaja. Kitab Muqaranah sembahyang karya al-Syeikh Ismail ibn 'Abdullah alKholidi berisi masalah-masalah yang berhubungkait dengan sembahyang iaitu niat. Bagi alSyeikh, niat merupakan rukun utama dalam semua aktiviti, tanpa niat semua ibadah tidak akan mendapatkan nilai di sisi Allah Subhanahu Wa Ta'ala. Muqaranah sembahyang ini dimaksudkan ialah niat ketika mengucapkan takbiratul Ihram mesti terus tanpa diberikan jarak dengan perkataan dan pikiran apapun. Antara "alif" yang ada pada "اله" huruf "ra" yang ada di akhir "أكبر" harus disambung tidak terpisah.

7) كتاب بداية الهداية di dalam kitab ini terdapat dua naskah iaitu kitab Bidayah al-Hidayah karya alSyeikh Muhammad Zain ibn Faqih Jalal al-Din al-'Asyi dan kitab yang ada di tepi ini berupa taqrirat (ulasan) dari pelbagai kata, istilah dan masalah yang ada dalam kitab Bidayah alHidayah, taqrirat ini sebagai karya dari al-Syeikh Ahmad ibn Muhammad Zain al-Fatani). Kitab Bidayah al-Hidayah karya alSyeikh Muhammad Zain ibn Faqih Jalal al-Din al-'Asyi ini menjelaskan isi kitab Matn Umm al-Barahin Imam al-Sanusi. Kitab ini satu dari banyak kitab yang menjadi syarh (penjelas) dari kitab induk Matn Umm al-Barahin imam Sanusi. Kitab ini juga menjelaskan pemikiran al-Syeikh Muhammad Zain dalam bidang aqidah ahl al-Sunnah wa alJama'ah. Kitab al-Taqrirat sebagai karya al-Syeikh Ahmad ibn Muhammad Zain al-Fatani berfungsi sebagai penjelas dari kitab Bidayah al-Hidayah. Kata, kalimat dan pelbagai masalah yang terdapat pada kitab asas diberikan ulasan agar lebih mudah difahami oleh para pengkaji dan pembaca kitab Bidayah al-Hidayah. Dua bayt syair pembuka pada halaman pertama kitab ini telah menegaskan fungsi tersebut; 


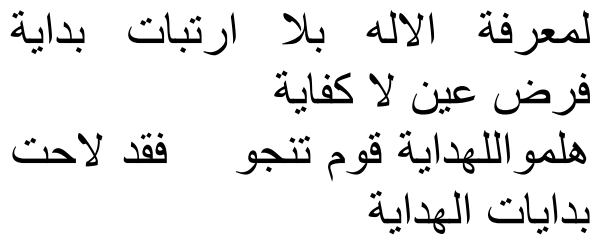

Untuk mengetahui sebenarbenarnya Tuhan,

itu pertama fardlu ain bukanlah kifayah

Pelajari kitab Bidayah al-Hidayah kalian akan selamat,

Penjelasan makna dan hakikat alTauhid ada dalam Bidayah alHidayah

8) كتاب مجموع ثناث رسائل dalam kitab ini terdapat 3 risalah, pertama risalah Umdat alMubtadi'în, kedua risalah berbicara segala nakjis yang dimaanfkan dan tidak dimaafkan dan ketiga qishah (cerita) Ashab al-Kahfi karya Muhammad Yasin ibn Tuan Muhammad Thahlahar). Kitab risalah Umdat al-Mubtadi'în berisi tentang segala hukum Qawâid al-Islâm dan al-Dîn, ertinya asal pangkal Islam dan agama sebagai pegangan dan I'tiqad yang tiada boleh berobah di dalam hati dan perbuatan pada segala anggota dan wajib atas segala orang yang mukallaf. Ada tiga bagian hukum dalam Islam iaitu wajib, mustahil dan jaiz. Kitab ini berisi 23 halaman iaitu dari halaman 1-23, risalah ini selesai dihimpun pada tarikh $16 \mathrm{hb}$ Jumadil 'Akhir tepat waktu Ashr pada hari Jumat, 1344 Hijriah. Kitab ini adalah karya alSyeikh Muhammad Ibn Thaha Hasan lahar.Kitab segala nakjis yang dimaafkan dan tidak dimaafkan. Sesuai dengan tajuk risalah ini, maka isi yang terkandung di dalamnya mengenai pelbagai nakjis dan cara-cara menghilangkannya. Kitab ini berisi 25 halaman, dimuali dari halaman 24-55. Kitab ini selesai dihimpun oleh alSyeikh Muhammad Yasin ibn Muhammad Thaha lahar pada tarikh 14hb, Zulqa'dah 1328 Hijriah. Kitab al-Durr al-Basim yang membincangkan qishah (cerita) Ashab al-Kahfi ditulis oleh al-Syeikhal-Fadlil Muhammad Ismail Daud al-Fatani pada hari Isnin, 19 hb Rajab waktu dhuha pada tahun 1310 Hijriah.

9) كتاب شرح رسالة المعاونة di dalam kitab ini terdapat dua buah kitab, kitab yang berada pada bagian tengah dinamakan kitab "Risalah al-Muawanah" dan yang berada di pinggir kitab dinamakan "Risalah alMuzakarah ma'a al-lkhwan alMuhibbin Min Ahl al-Khair wa alDin". Kedua-dua kitab ini merupakan karya al-Sayyid alSyarif 'Abbdullah ibn 'Alwi ibn Muhammad al-Haddad alHusaini. Kitab Risalah alMuawanah wa al-Mudzaharah wa al-Muwazarah li al-Raghibîn Fî Sulûki Tharîq al-'Ākhirah, merupakan karya al-Sayyid alSyarif 'Abbdullah ibn 'Alwi ibn Muhammad al-Haddad al-Husaini yang berkaitan dengan Sulûk (akhlak/perilaku) menuju akhirat. Kitab ini terdiri dari 40 halaman dan tersusun dari 40 pasal. Kitab Risalah al-Muzakarah ma'a alIkhwan al-Muhibbin Min Ahl alKhair wa al-Din merupakan kitab 
yang ditulis oleh al-Sayyid sendiri terkait dengan hasil muzakarah beliau dengan sahabat-sahabat beliau yang cinta terhadap kebajikan dan agama. Kitab ini secara khusus membahas masalah al-Taqwa yang terdiri dari 16 pasal dan penutup.

10) كتاب مفتاح الجنة di dalam kitab ini terdapat 5 buah kitab, pertama kitab Miftâhul Jannah karya Muhammad Thîb ibn Mas'ud alBanjari, kedua kitab Ushul alTahqî́q pada ilmu Ushul al-Din tiada disebutkan penulisnya kerana takut riya', ketiga kitab Mauidzat li An-Nâs pada menyatakan kaifiyat sembahyang dan segala rukunnya, tidak diketahui penulisnya kerana takut riya' dan kitab keempat Kitab Tajwid al-Qur'an. Satu kitab yang kelima berada pada tepi kitab sebagai Hâmisy bernama "risalah Asrar al-Din Li Ahl alYaqîn".Kitab Miftâhul Jannah Fî Bayân al-'Aqidah, karya Muhammad Thîb ibn Mas'ud alBanjari. Kitab ini membincangkan persoalan ilmu ushul al-Din, kitab ini ditulis dengan bahasa Melayu setelah melihat banyak penuntutpenuntut orang Jawi termasuk orang Melayu, kitab ini merupakan syarh (penjelasan) dari kitab asal Matn Umm alBarahin dengan memberikan tambahan dalil-dalil pada masalah-masalah yang memerlukan dalil. Kitab ini selesai ditulis pada hari Isnin 16 hari bulan Syawal tahun 1274 .
كتاب اليو اقيت والجواهر فى عقوبة (11) أهل الكبائر di dalam kitab ini terdapat dua buah kitab, iaitu kitab al-Yawâqît wa al-Jawâhîr fî 'Uqûbat Ahl al-Kabâir, adalah kitab yang diterjemahkan dari kitab berbahasa Arab karya alSyeikh 'Abdul Wahhâb alSya'rânî ke dalam bahasa Melayu. Kedua kitab Uqûd alLujjain Fî Huqûq al-Zaujain karya al-SyeikhNawawi al-Bantani). Kitab al-Yawâqît wa al-Jawâhîr fî 'Uqûbat Ahl al-Kabâir, adalah kitab yang diterjemahkan dari kitab berbahasa Arab karya alSyeikh'Abdul Wahhâb al-Sya'rânî ke dalam bahasa Melayu oleh alSyeikhMuhammad 'Ali ibn 'Abd al-Rasyid ibn 'Abdullah al-Jâwî al-Qâdhi al-Sumbâwî. Kitab menerangkan dahsyatnya siksa yang akan diperolehi bagi pelaku dosa besar pada hari kiyamat. Kitab ini disusun atas 12 bab. 1) Siksa bagi orang yang meninggalkan sembahyang, 2) siksa bagi orang durhaka pada ibu dan bapa', 3) siksa bagi orang yang minum araq dan tuak, 4) siksa bagi orang yang berzina, 5) siksa bagi orang yang liwath, 6) siksa bagi orang yang makan riba, 7) siksa bagi orang yang meratap, 8) siksa bagi orang yang tidak mengeluarkan zakat, 9) siksa bagi orang yang membunuh orang Islam tanpa syarat, 10) siksa bagi orang perempuan dan lelaki yang tidak melaksanakan tugas dan kewajipannya, 11) Susah dan kesakitan siksa di hari kiyamat, 12) sifat syurga dan orang yang 
menjadi ahli syurga. Kitab ini selesai di terjemahkan pada hari isnin setelah Ashr, $18 \mathrm{hb}$ Zulqa'dah, 1243 di Makkah alMukarramah. Kitab Uqûd alLujjain Fî Huqûq al-Zaujain karya al-SyeikhNawawi al-Bantani. Kitab ini berisi tentang hak-hak suami dan isteri.

12)

كتاب مفتاح المريد فى علم التوحبد)(di dalam kitab ini terdapat 3 kitab secara bersamaan dan 1 kitab di bagian hâmisy (tepi). Kitab pertama Miftâhul Murîd fî IIm al-Tauhîd karya Zain al'Abidîn ibn Muhammad al-Fatani. Kedua Risalah yang bicara tentang sebab murtad oleh Umar ibn Zain al-'Abidin Fatani. Ketiga Risalah Nadzam Melayu tentang ilmu tauhid dan nasihat karya Haji Ahmad ibn 'Abdurrauf Malaka. Dan kitab keempat yang ada pada bagian tepi ialah kitab Syuabul Imân dinuqilkan dari kitab Muta'allim karya alSyeikhDaun ibn 'Abdullah alFatani. Kitab Miftâhul Murîd fî IIm al-Tauhîd karya Zain al-'Abidîn ibn Muhammad al-Fatani. Kitab ini membincangkan ilmu tauhid yang diawali dengan pembahagian hukum akal menjadi tiga (Wajib, Mustahil dan Jaiz/harus). Kemudian diteruskan dengan bicara sifat-sifat Allah yang 20 sifat.Kitab Risalah yang bicara tentang sebab murtad oleh Umar ibn Zain al-'Abidin Fatani. Kitab ini membincangkan sebabsebab terjadinya murtad pada diri seseorang. Mengetahui Lafazd, perbuatan dan i'tiqad yang menyebabkan seseorang menjadi murtad hukumnya wajib bagi setiap muslim dan muslimat juga Jin-jin Islam. Kitab Risalah Nadzam Melayu tentang ilmu tauhid dan nasihat karya Haji Ahmad ibn 'Abdurrauf Malaka. Kitab ini merupakan karya beliau dalam bentuk syair (nadzam), isi kandungannya mengenai ilmu tauhid, nadzam rasul dan nadzam nasihat. Kitab Syuabul Imân dinuqilkan dari kitab Muta'allim karya al-SyeikhDaun ibn 'Abdullah al-Fatani. Kitab yang keempat ini berada di bahagian tepi dari kitab Miftâh alMurîd. Kitab ini membincangkan cawangan iman, cawangan iman itu menjadi 77 cawang.

\section{3) Keunikan kutipan}

Keunikan lain dari kitab Turath ialah cara (metod) mengambil kutipan dari ulama-ulama lain. Sepertimana dicontohkan oleh al-SyeikhDaud ibn 'Abdullah al-Fatani dalam kitab al-Durr al-Thamin. Pernyataan beliau mengenai 10 mabâdi' yang mesti dimiliki oleh setiap orang yang belajar ilmu.

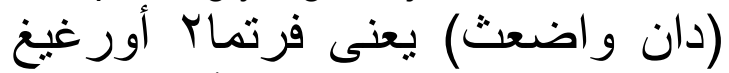

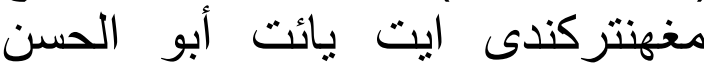

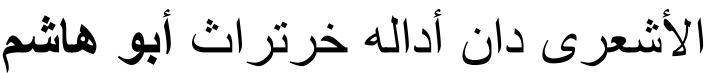
الجبائى ضورو أبو الحسن الأشعرى لاض بفأ تيري سوامى إيبوث.. . . (Al) Syaikh Daud ibn 'Abdullah al-Fatani.

(t.th).3

Al-Syeikh Muhammad Thib ibn Mas'ud al-Banjârî dalam kitab Miftâh alJannah mengambil pandangan al- 
Syeikh Nasafi dalam keutamaan "basmalah".

(فائدة) اين سوات فائدة كات شيخ

نسفى برمول سضل كتاب بغدتورنكن درفد لاغت كفد دنيا ايت سراتس أمفت صحف اكن نبى شيش أنم فوله دان نبحى إبراهيم تيض فوله اكن نبى إنى موسى دهول درفد توراة سفولأله دان

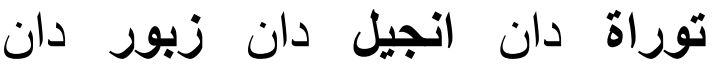
فرقان، ملك سضل معنى كتاب ابت

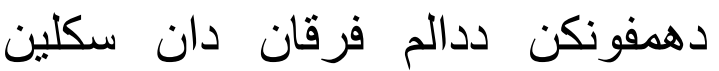

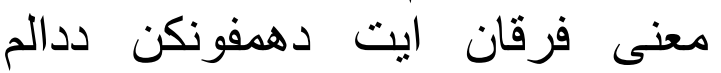
فاتحة دان سضل معنى فاتحة ابت دهمفونكن ددالم بسم الله دان سضل دهل معنى بسم الله ايت دهمفونكن ددالم باءث.

(Muhammad Thib ibn Mas'ud alBanjârî. (t.th).2)

Sayyid Syarif 'Abdullah ibn 'Alawi dalam kitab Risâlah al-Muâwanah wa al-Muzâharah wa al-Muwâzarah li alRâghibîn Min al-Mukminîn fî Sulûki Tharîq al-'Ākhrati menjelaskan hakikat makna al-Taqwa sepertimana dalam alQur'an surat al-Baqarah 183 yang dijelaskan oleh Imam al-Ghazali.

(فصل) قال الإمام الغزالى التقوى فى في القرآن تطلق على ثلاث معان أحدها الخثية و الهيبة و الثانى بمعنى الطاعة ولى والعبادة

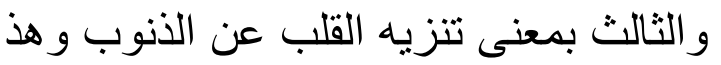

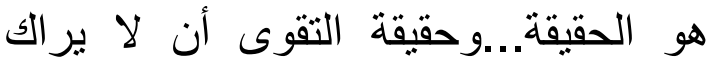
مولاك حيث نهالك و لا يفقدك حيث أمرك. (Syarif 'Abdullah ibn 'Alawi. (t.th).5).
Maksudnya;" al-Taqwa dalam al-Qur'an terbahagi menjadi tiga perkara, pertama bererti takut (al-Khashyah), kedua, taat dan beribadah dan ketiga, bererti pembersihan hati dari perkara-perkara dosa, makna terakhir inilah yang menjadi hakikat dari altaqwa. Maka hakikat al-taqwa ialah engkau tidak akan pernah dilihat oleh Allah dalam perbuatan maksiat dan tidak pernah mengurangkan apa-apa yang diperintahkannya".

\section{Sejarah Pengajaran Kitab Turath di Negara Brunei Darussalam}

\section{A. Maktab Perguruan Ugama Seri Begawan (MPSB)}

Tiga puluh Sembilan tahun sebelum terwujudnya Kolej Universiti Perguruan Ugama Seri Begawan, telah di isytiharkan satu lembaga keagamaan yang fokus mengajarkan ilmu-ilmu ugama Islam di Negara Brunei Darussalam, lembaga tersebut dinamakan Maktab Perguruan Ugama Seri Begawan. Berdirinya maktab ini pada tahun 8 Julai 1968 KDYMM meletakkan batu asas Maktab Perguruan Ugama Seri Begawan, dan beroperasi 8 Januari 1972.

Adapun tujuan Maktab Perguruan Ugama Seri Begawan ditubuhkan ialah:

Pertama; Melatih dan mengadakan guru- guru ugama yang layak lagi sesuai bagi mengajar matapelajaran-matapelajaran ugama, khasnya di sekolah-sekolah dan amnya di lain-lain yayasan di negeri ini yang memerlukan pengajaran Ugama Islam dengan tujuan membentuk satu rupa bangsa yang mempunyai Ugama Islam sebagai asas masyarakat mengikuti aliran masa dan mendukung Perlembagaan Negara Brunei Darussalam.

Kedua;Mengadakan beberapa kursus yang lain seperti Perguruan membaca al- 
Qur'an, Muballigh dan seumpamanya dari satu masa ke satu masa.

Ketiga; Mengadakan beberapa kursus pembaharuan dan penyesuaian, bukan sahaja bagi guru-guru dalam lapangan matapelajaran-matapelajaran ugama, bahkan juga bagi pegawai-pegawai di Kementerian Hal Ehwal Ugama dalam kursus penyesuaian, bukanlah satu harapan yang mustahil jika Maktab mengadakannya bagi pegawai-pegawai Kerajaan daripada lain-lain Jabatan bagi menimbulkan satu fahaman pegawai untuk menimbulkan keharmonian dan kecekapan dalam usaha untuk membangun Negara dan bagi menuju kea rah Islam dijadikan suatu cara hidup yang lengkap serta Islam dijadikan Ideologi Negara.

Keempat; Adalah juga menjadi suatu harapan besar bahawa Maktab akan maju ke satu arah yang merupakan ianya sebagai

\section{No Nama kitab \\ 1 Aqîdah an-Nâjîn Fî llm Ush I al-Dîn \\ 2 Risâlah al-Tauhîd \\ 3 Mathla' al-Badrain wa Majma' al-Bahrain \\ 4 Penawar Bagi Hati \\ 5 Tanbih al-Ghâfilîn}

Bidang
Aqidah
Aqidah
Feqh
Tasawuf
Tasawuf

Kolej Univesiti Perguruan Ugama Seri Begawan (KUPU SB)

Kolej Universiti Perguruan Ugama Seri Begawan (KUPU SB) ditubuhkan pada awal Tahun Baru Hijrah 1428 bersamaan dengan 20 Januari 2007 , iaitu berikutan pengisytharan Kebawah Duli Yang Maha Mulia Paduka Seri Baginda Sultan Haji Hassanal Bolkiah Mu'izzaddin Waddaulah ibni Al-Marhum Sultan Haji Omar ali saifuddien Sa'adul Khairi Waddien, Sultan dan Yang DiPertuan Negara Brunei Darussalam dalam titah baginda sempena sambutan awal Tahun Baru Hijrah 1428. Baginda telah menitahkan bagi penaikan taraf kepada peringkat Kolej
Pusat Penyelidikan dalam perkara-perkara ugama dan perkembangannya terhadap negara ini amnya.

Kelima; Meninggikan nilai pelajaran supaya ia bukan saja memberi perkhidmatan kepada pembentukan satu negara dan masyarakat Negara Brunei Darussalam yang maju dan dinamis, tetapi boleh dan layak untuk memberi sumbangan perkhidmatan di lain negara di rantau ini dalam lapangan ugama. (Ghazali bin Basri, et.all. (2009).02)

Tahun 2007 MPUSB dinaikkan taraf Kolej Perguruan Ugama Seri Begawan ( KUPU SB)

Antara pengajaran ugama yang diajarkan di Maktab Perguruan Ugama Seri Begawan ialah kitab-kitab turath seperti tergambar pada chart berikut ini:

\section{Penulis \\ Zain al-'Abidin ibn Muhammad al-Fathani \\ 'Abdul Ghani Yahya dan Umar Yusuf Muhammad bin Ismail Daud Fathani \\ 'Abdul Qadir bin 'Abdul Muthalib \\ 'Abdullah bin 'Abdul Mubin}

Universiti daripada peringkat Maktab Perguruan Ugama. KUPU SB dihasratkan menjadi sebuah institusi perguruan ugama yang unggul, menjadi kebanggaan dan memenuhi keperluan Negara serta bersedia membuka pintunya kepada pelajar luar Negara.

Pada masa ini KUPU SB mempunyai tiga buah fakulti dan enam buah pusat iaitu Fakulti Usuluddin, Fakulti Syariah, Fakulti Pendidikan, Pusat IImu Teras, Pusat Bahasa, Pusat Pengajian Lepas ljazah dan Penyelidikan, Pusat Pengkajian Kefahaman Ahli Sunnah Waljama'ah, Pusat Multimedia \& Teknologi dan Pusat Penerbitan. KUPU SB 
akan sentiasa memantapkan program latihan perguruannya, menggiatkan kajian dan penyelidikan serta penerbitan dan menjalinkan kerjasama dengan institusi pengajian tinggi yang lain untuk pembangunan program, penyelididkan, pengurusan dan sumber tenaga manusia.

Melalui pengintegrasian ilmu, latihan, kajian, perkhidmatan, teknologi, ketrampilan dan jati diri berasaskan prinsip-prinsip Islam dan falsafah Negara, diharapkan KUPU SB akan dapat melahirkan pendidik yang berwibawa sebagai hamba dan khalifah Allah dalam membentuk masyarakat dan bangsa yang berilmu, beramal dan bertaqwa, serta mendukung Islam sebagai ugama rasmi dan falsafah Negara Melayu Islam Beraja.

Setiap mahasiswa yang mengambil program Sarjana Muda Perguruan Ugama Seri Begawan (SMPU) dan Diploma Tertinggi Perguruan Ugama Seri Begawan diwajibkan mengambil kursus Kitab Turath sebagai kursus IImu Teras. Masing-masing program dari tahun satu (1) dan tahun dua (2) diwajibkan mempelajari lima (5) buah kitab turath. Dua (2) buah kitab pada tahun satu dan tiga buah kitab pada tahun dua.

Kitab-kitab yang akan diajarkan pada tiap-tiap tahun dan program seperti yang tersebar pada chart berikut:

\section{1) Mahasiswa Sarjana Muda Perguruan Ugama Seri Begawan (SMPU)}

$\begin{array}{cll}\text { No } & \text { Nama kitab } & \text { Bidang } \\ & \text { Al-Durr al-Thamin } & \text { Al-Aqidah } \\ 2 & \text { Tanbih al-Ghafilin } & \text { Al-Hadits } \\ 3 & \text { Idhah al-Albab li Murid } & \text { Al-Feqh } \\ & \text { an-Nikah li al-Shawab } & \\ 4 & \text { Munyah al-Mushalli } & \text { Al-Feqh } \\ 5 & \text { Minhaj al-'Abidin llaa } & \text { Al-Tasawuf } \\ & \text { Jannati Rabbil 'Alamin } & \end{array}$

Penulis

Al-Syaikh Daud ibn 'Abdullah al-Fathani Al-Syaikh 'Abdullah bin 'Abdul Mubin Al-Syaikh Daud ibn 'Abdullah al-Fathani

Al-Syaikh Daud ibn 'Abdullah al-Fathani Al-Syaikh Daud ibn 'Abdullah al-Fathani

\section{2) Mahasiswa Diploma Tertinggi Perguruan Ugama Seri Begawan (DTPU)}

\begin{tabular}{|c|c|c|}
\hline No & Nama Kitab & Bidang \\
\hline 1 & Al-Durr al-Thamin & Al-Aqidah \\
\hline 2 & Tanbih al-Ghafilin & Al-Hadits \\
\hline 3 & $\begin{array}{l}\text { Idhah al-Albab li Murid } \\
\text { an-Nikah li al-Shawab }\end{array}$ & Al-Feqh \\
\hline 4 & Munyah al-Mushalli & Al-Feqh \\
\hline 5 & $\begin{array}{l}\text { Minhaj al-'Abidin Ilaa } \\
\text { Jannati Rabbil 'Alamin }\end{array}$ & Al-Tasawuf \\
\hline
\end{tabular}

\section{Penulis}

Al-Syaikh Daud ibn 'Abdullah al-
Fathani
Al-Syaikh 'Abdullah bin 'Abdul Mubin
Al-Syaikh Daud ibn 'Abdullah al-
Fathani
Al-Syaikh Daud ibn 'Abdullah al-
Fathani
Al-Syaikh Daud ibn 'Abdullah al-
Fathani




\section{3) Orang awam}

Program Pengajian Kitab Turath untuk orang awam ini dimuali dari tahun 2011 sebagai salah satu resolusi seminar Serantau Kitab Turath Melayu. Program ini diwujudkan untuk memberikan peluang bagi orang-orang awam yang hendak mengaji dan

$\begin{array}{cll}\text { No } & \text { Nama Kitab } & \text { Bidang } \\ 1 & \begin{array}{l}\text { Tajul 'Arus } \\ \text { Mathla' Badrain } \\ \text { wa Majma' al- } \\ \text { Bahrain }\end{array} & \begin{array}{l}\text { Al-Tasawuf } \\ \text { Al-Feqh }\end{array} \\ 3 & \begin{array}{l}\text { Bidayah al- } \\ \text { Hidayah } \\ 4\end{array} & \text { Al-Aqidayah al-Sâlikîn } \\ 5 & \begin{array}{l}\text { Al-Aqidah, al-Feqh wa } \\ \text { al-Tasawuf }\end{array} \\ \text { Tal-Tasawuf al-Ghafilinn } & \text { Al-Tasaw }\end{array}$

\section{Pengajaran Kitab Turath di berbagai Masjid}

Untuk memperluas peluang orang awam mengikuti kajian kitab-kitab turath Melayu, maka Kolej Univesiti Perguruan Ugama Seri Begawan (KUPU SB) berkongsi dengan jabatan Hal Ehwal masjid-Negara Brunei Darussalam bagi mengadakan taklimtaklim kitab turath Melayu di masjid-masjid sekitaran Brunei dan Muara. Antara matlamat yang ingin dikongsikan ialah;

1. Memperkenalkan kitab turath Melayu sebagai bahan bacaan utama bagi setiap orang ramai.

2. Memberikan penerangan kepada orang ramai terkait denga nisi kitab mendapatkan informasi terkait ilmu-ilmu yang tersembunyi di dalam kitab-kitab turath. Program ini dijalankan pada hari Jum'at dan hari ahad, masing-masing mengajarkan dua (2) buah kitab, mulai dari sesi pagi 8:00-9:00 dan pukul 9:00-10:00.

\section{Penulis}

Tajuddin ibn 'Athaillah al-Sakandari Muhammad bin Ismail Daud Fathani

Muhammad Zain ibn Faqih Jalaluddin

'Abdush-Shamad al-Palimbani

'Abdullah bin 'Abdul Mubin

\section{Nama-nama masjid dan kitab turath yang diajarkan}

$\begin{array}{ll}\text { No } & \text { Nama Kitab } \\ 01 & \text { Dawâul Qulub ilâ 'Allâmil Ghuy b } \\ 02 & \text { Tajul 'Arus }\end{array}$

Bidang Penulis

$\begin{array}{ll}\text { Al-Tasawuf } & \text { Al-Syaikh Ahmad bin } \\ & \text { Muhammad Chotib Langgien } \\ \text { Al-Tasawuf } & \begin{array}{l}\text { Al-Syaikh Utsman bin al-Hajj } \\ \text { Syihabuddin al-Pontiana'i }\end{array}\end{array}$




$\begin{array}{ll}\text { No } & \text { Nama Kitab } \\ 03 & \begin{array}{l}\text { Minhâj al-'Abidîn Ilâ Jannati Rabbil } \\ \text { 'Alamîn }\end{array} \\ 04 & \begin{array}{l}\text { Al-Minah al-Saniyyah ala al- } \\ \text { Washiyyat al-Mathb liyyah } \\ 05\end{array} \\ 06 & \text { Hikam Jawi } \\ 07 & \text { Tafsir al-Qurthuby } \\ 08 & \text { Feqh Minhaji } \\ 09 & \text { Matn Sanusiyyah } \\ 10 & \text { Bidayah al-Hidayah }\end{array}$

\section{B. Asas pengajaran Kitab Turath}

Sebagaimana diketahui bahawa kitab turath baik yang masih berbentuk manuskrip (makhthuthât), kitab Arab ataupun yang Jawi, berbeza dengan kitab-kitab dan buku-buku moden lainnya. Selain dalam bentuk cover judul dan isi, kitab turath juga berbeza metod penulisannya. Kerana itulah maka dalam mengkaji dan mengaji kitab turath memiliki metod yang berbeza pula.

Sebelum membincangkan metod yang akan digunakan dalam mengkaji dan mengaji kitab turath, dalam tulisan ini akan diberikan penerangan terkait tujuan mengkaji dan mengaji kitab turath. Terdapat empat kemahiran yang ingin dicapai dalam mengkaji dan mengaji kitab turath, iaitu:

Pertama; Mâhir fi al-qirâ’ah ( ماهر فى ماءو (أقرة : Mahir dalam membaca, ini bermakna bahawa setiap pelajar (orang yang mengkaji dan mengaji) kitab turath dituntut untuk dapat membaca. Membaca kitab-kitab turath yang masih berbentuk manuskrip (Arab dan Melayu), mesti memiliki keahlian yang lebih spesial kerana bahasa, huruf, ejaan dan kertas yang digunakan masih menggunakan

\begin{tabular}{|c|c|}
\hline Bidang & Penulis \\
\hline Al-Tasawuf & $\begin{array}{l}\text { Al-Syaikh Daud bin 'Abdullah al- } \\
\text { Fathani }\end{array}$ \\
\hline Al-Hadits & $\begin{array}{l}\text { Al-Syaikh 'Abdul Wahhab al- } \\
\text { Sya'rani }\end{array}$ \\
\hline Al-Tasawuf & $\begin{array}{l}\text { Al-Syaikh Ibn ' Athaillah al- } \\
\text { Sakandari }\end{array}$ \\
\hline Tafsir & Al-syaikh Ahmad Showi al-Mâliki \\
\hline Tafsir & $\begin{array}{l}\text { Al-Syaikh Abu 'Abdullah } \\
\text { Muhammad bin Ahmad bin Abu } \\
\text { Bakr Al-Anshari al-Qurthubi }\end{array}$ \\
\hline Feqh & $\begin{array}{l}\text { Dr Mustafa Al-Khin, Dr Mustafa } \\
\text { al-Bugha \& Ali Asy-Syarbaij. }\end{array}$ \\
\hline Aqidal & $\begin{array}{l}\text { Al-Sayyid Muhammad bin Yusuf } \\
\text { bin al-Husain al-Sanusi }\end{array}$ \\
\hline Aqidah & $\begin{array}{l}\text { Al-Syaikh Muhammad Zain bin } \\
\text { Faqih Jalaluddin }\end{array}$ \\
\hline
\end{tabular}

bahasa, huruf, ejaan dan kertas lama (klassik). Kajian dan pengajian pada tingkat ini dapat dilakukan dengan memahami ilmu filologi, kodikologi, tahqiq dan juga tashih.Membaca kitab turath moden (cetakan baru) yang berbahasa Arab juga memiliki kesukaran bagi sesiapa saja yang belum pemah mempelajari metod membaca dan memahami kitab bahasa Arab. Membaca kitab-kitab yang berbahasa Arab dapat menggunakan metod al-Arabiyyah li Ghair an-Nasyiin, metod alQira'ah wa al-Fahm matn al-'Ajurumiyyah, metod al-Arabiyyah al-Mustaqilli dan Metod Memahami Bacaan Sembahyang \& alQur'an. Membaca kitab turath berbahasa Melayu-Jawi lebih mudah dibandingkan dengan bahasa Arab dan juga manuskrip kerana kitab-kitab ini merupakan bahasabahasa yang sudah kita pahami, tapi ada beberapa kata dan kalimat yang masih menggunakan kata dan kalimat masa silam yang perlu dicari tahu makna dan ejaan yang sebenar-benamya. Dalam kitab turath juga banyak istilah yang diambil daripada bahasa Arab, kerana itulah mesti dipahami dan dipelajari dengan sungguh-sungguh. 
Kedua; Mâhir fi al-Kitabah ( ماهز فى ) الكتابة): mahir dalam menulis, menyalin kembali seperti sedia ada dan menyalin kembali dengan melakukan perobahan (memodenkan). Ada dua cara yang dapat dilakukan untuk memberikan kemahiran dalam menulis.Menulis kembali teks kitab turath apa adanya, tidak dibenarkan merobah apapun baik kata, kalimat atau juga tulisan yang mungkin salah atau tersilap tulis oleh penulis ataukah penyalin atau mungkin saat dicetak. Aktiviti seperti ini dikenal dengan istilah menyalin.Menulis kembali teks kitab turath dengan melakukan pembaikan pada teks kata, kalimat dan istilah yang tersilap. Pembaikan ini dapat dilakukan dengan cara membuat footnote (catitan kaki) di bawah. Dalam penulisan ini juga dapat memberikan taudhih (penerangan) terhadap kalimat atau istilah yang tidak dipahami atau susah untuk dipahami oleh para pembaca, pengkaji mahupun pengaji. Di dalam proses ini juga dapat memberikan tashih sederhana terhadap ayat-ayat al-Qur'an dengan memberikan nama surat dan nombor surat pada setiap ayat al-Quran yang ada. Dan juga memberikan sanad dan rawi (takhrij) sederhana pada setiap al-hadits yang ada pada kitab turath.

Ketiga; Mâhir fi al-Fahm ( ماهر فى القهم): Mahir dalam memahami ini, tidak akan dapat dijalankan jika belum mahir dalam membaca mahupun mahir dalam menulis, jadi yang lebih awla dilakukan ialah belajar membaca dan juga menulis, baru dapat memahami teks kitab turath dengan baik dan benar. Kemahiran memahami sangat ditentukan oleh kemampuan seorang pengkaji, pengaji mahupun penuntut dalam memahami teks dan konteks ayat-ayat kitab turath. Panduan untuk memahami kitab turath; Perhatikan dan cari pengertian kata-kata yang ada di dalam kitab turath, seperti "تتاول" dapat bererti “"أكل " (makan), dapat pula bererti “ (membaca). Perhatikan dan cari pengertian/definisi kalimat yang ada dalam kitab turath, seperti "نتاولت الكتاب "kalimat ini bererti "membaca", tapi kalau kalimat ini berbunyi "نتاولت الفطور" maka dia bererti "sarapan pagi/breakfast)". Perhatikan kata atau kalimat sebelum dan sesudah kalimat yang ingin kita pahami.

Keempat, Mâhir fi al-Ta'lim ( ماهز فى التعليح): mahir dalam mengajar, yang keempat ini merupakan tujuan akhir dari pengajaran kitab turath. Selain untuk bekal dir sendiri, kemahiran dalam mengajar ini merupakan bekal untuk memberikan pemahaman kepada orang lain. Dengan mahir mengajar bererti kitab turath akan dapat dipahami tidak hanya oleh sekelompok orang-orang tertentu, melainkan dapat memberikan kepahaman kepada masyarakat awam. Prinsip kemahiran ini dapat dilihat dalam hadith Nabi yang menjelaskan tentang pentingnya mengamalkan ilmu yang sudah diketehui.

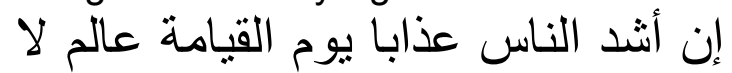
بنفعه الله بعلمه. (رو اه الطبر اني) Maksudnya: Sesungguhnya orang yang paling berat siksanya di hari kiyamat ialah orang 'alim yang tidak memberi manfaat (taat kepada) Allah akan ilmunya.

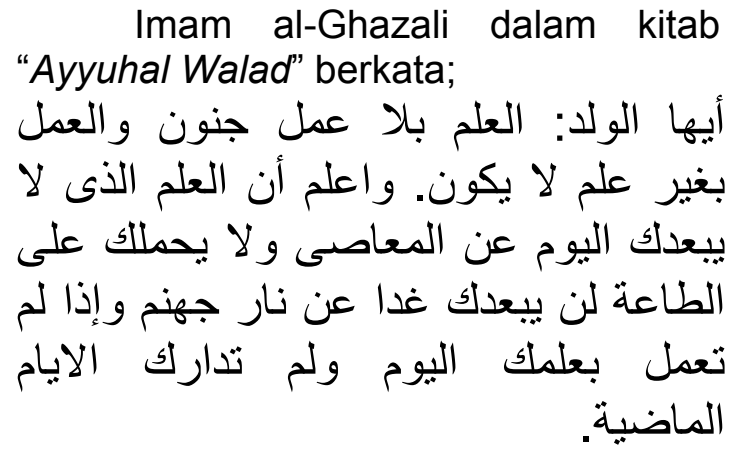


Maksudnya : Wahai anakku!; IImu tanpa amal seperti orang gila dan amal tanpa ilmu tidak akan pernah dapat memberikan manfaat. Ketahuilah bahawa ilmu yang tidak dapat membuatmu menjauhi perbuatan maksiat dan tidak mendekatkan dinimu untuk berbuat taat, maka tidak akan pernah dapat menjauhlkanmu dari siksa neraka dan jika tidak engkau beramal dengan ilmumu pada saat ini maka tidak akan pemah engkau dapatkan kemuliaan hari esok. (Hujjat al-Islam Imam al-Ghazali. (1433/212).18-19.

Nasihat imam al-Ghazali tersebut menjelaskan bahawa ilmu yang tidak diamalkan oleh yang mempunyai ilmu sama saja dengan orang gila yang tidak memiliki akal sehat. Kerana dengan ilmu seharusnya dapat membantu kita bagi mendekatkan diri kepada Allah Subhanahu Wa Ta'ala, jika tidak, maka ilmu yang kita miliki tidak akan dapat digunakan untuk menghindari panasnya api neraka Allah dan tidak dapat membantu kita untuk membedakan mana yang baik dan mana yang buruk.

\section{Metode mengajarkan kitab turath}

Sebelum kita mengetahui metod mempelajari kitab turath, sebaiknya kita memahami apa tujuan kita mempelajari kitab-kitab turath di Koleh Universiti Perguruan Ugama Seri Begawan (KUPU SB). Tujuan pembelajaran Kitab Turath di KUPU SB terbahagi menjadi dua ialah:

\section{Tujuan 'Am}

1) Mengembalikan Tradisi
pengajian Kitab Turath Melayu bagi Guru-guru Ugama Tradisional Brunei

2) Menjadikan KUPU SB sebagai Punggur pengajaran Kitab Turath Melayu

3) Membudayakan dan memberigakan Kitab Turath
Melayu sebagai asas pengajian Intelektual Muslim

4) Melestarikan tulisan Jawi sebagai warisan Bangsa Melayu

5) Melazimkan guru-guru ugama menulis, membaca dan menjadikan Kitab Turath Melayu sebagai rujukan asasi dalam kajian-kajian IImiah.

6) Membiasakan guru-guru ugama untuk menjadikan Kitab Turath sebagai bahan pengajaran di sekolah-sekolah ugama mahupun di masyarakat

\section{Tujuan Khas}

1) Mahasiswa dapat membaca Kitab Turath Melayu dengan baik.

2) Mahasiswa dapat menulis kembali teks-teks kitab Turath dengan sempurna

3) Mahasiswa dapat menyalin teksteks Kitab Turath Melayu ke dalam ejaan rumi

4) Mahasiswa dapat mentahqiq teks-teks Kitab Turath Melayu ke dalam bahasa yang mudah

5) Mahasiswa dapat memahami teks-teks kitab Turath Melayu dan menerangkan isi kandungan kitab dengan jelas

6) Mahasiswa dapat membezakan antara nash al-Qur'an, matan hadith dan qaul para Ulama yang terdapat dalam Kitab Turath Melayu

7) Mahasiswa dapat mengajarkan kitab turath Melayu kepada masyarakat awam. 


\section{1) Metod pengajaran Kitab Turath Melayu}

Manusia sebagai makhluk sosial sekaligus sebagai makhluk religios sepertimana ditegaskan Allah Subhanahu wa Ta'ala dalam al-Qur'an sebagai makhluk tersempurna jika dibandingkan dengan makhluk-makhluk lainnya.

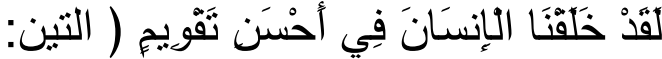

Tafsirnya: "Sesungguhnya Kami telah menciptakan manusia dalam bentuk yang sebaik-baiknya (dan berkelengkapan sesuai dengan keadaannya)".

Di samping manusia sebagai makhluk yang paling sempurna, ia juga diciptakan Allah sebagai makhluk yang lemah, sepertimana ditegaskanNya dalam al-Qur'an:

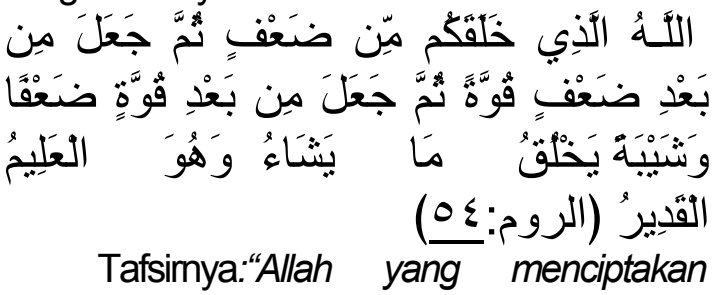
kamu bermula dengan keadaan lemah, selepas berkeadaan lemah itu la menjadikan kamu kuat. Setelah itu la menjadikan kamu lemah pula serta tua beruban. la menciptakan apa yang dikehendakiNya, dan Dia lah jua yang Maha Mengetahui, lagi Maha Kuasa".

Dari kedua ayat tersebut jelas terlihat bahawa manusia selain menjadi makhluk paling sempuma dengan akal fikirannya, juga Allah ciptakan sebagai makhluk lemah yang memerlukan bantuan orang lain untuk dapat hidup mendiri sesuai yang diharapkan.

Dalam proses mencari dan memberikan bantuan terhadap manusia diperlukan media atau cara yang sesuai dengan sifat dan karakter manusia. Melihat itulah metod sebagai media dalam memberikan bantuan sangat diperlukan, sehingga dalam sebuah ungkapan dikatakan: الطريقة أهم من المادة

"Metod lebih utama (penting) dibandingkan dengan materi".

Metod dalam proses belajar dan mengajar sangatlah banyak, sehingga seorang guru ataupun pensyarah mestilah mengetahui ragam metod agar boleh menggunakannya dalam proses belajar dan mengajar. Masing-masing maddah dapat menggunakan metod yang berbeza kerana berbeza tujuan yang akan dicapai.

Kitab Turath sebagai salah satu maddah yang wajib dipelajari oleh semua mahasiswa di KUPU SB juga memerlukan metod sehingga dapat mencapai tujuan yang diasaskan. Metod-metod inilah yang akan dijelaskan secara terperinci dalam buku panduan mempelajari Kitab Turath.

Secara garis besar ada empat model metod yang sering digunapakai di pesantren dalam mempelajari kitab-kitab Turath termasuk di dalamnya Turath Melayu dan juga Arab yang popular disebut "kitab kuning".

\section{Weton}

Istilah weton berasal dari kata wektu (Jawa) yang berarti waktu. Disebut metod weton karena pengajian diberikan pada waktu-waktu tertentu, seperti sebelum atau sesudah solat fardhu. Metod ini merupakan metode kuliah, dimana para santri mengikuti pelajaran dengan duduk di sekeliling Kyai. Sementara sang Kyai menerangkan, para santri menyimak kitab masing-masing dan membuat catatan yang dikenal dengan sitilah dabit (catatan dipinggir-umumnya dengan menggunakan bahasa melayu).

\section{Sorogan}

Kata ini berasal dari sorog (bahasa Jawa), yang berarti menyodorkan. Disebut 
sorogan karena setiap santri menyodorkan kitabnya di hadapan Kyai atau asisten Kyai.Metod ini mengugunakan pendekatan belajar individual, dimana seorang santri berhadapan denagn seorang guru, sehingga interaksi langsung diantara keduanya. Sistem sorogan ini terbukti sangat efektif dalam mempersiapkan santri untuk menjadi seorang yang alim. Pasalnya, metod ini memungkinkan seorang guru untuk mengawasi, menilai, dan membimbing secara maksimal kemampuan santri, khususnya dalam menguasai bahasa Arab.

\section{Al-Halâqah}

Metod ini merupakan kelompok kelas dalam sistem bandongan. Metod ini difahami sebagai cara belajar sekelompok santri dibawah bimbingan seorang guru atau belajar bersama dalam satu tempat. Halâqah juga difahami sebagai kegiatan diskusi untuk memahami sebagai kegiatan diskusi untuk mempertanyakan kemungkinan benar salahnya pesan yang diajarkan kitab, tetapi untuk memahami apa maksud yang diajarkan oleh kitab.

\section{Al-Hifz (Hafalan)}

Di Pesantren, metod ini umumnya dipakai untuk menghafal kitab-kitab tertentu. Namun, sering juga dipakai untuk menghafal Al-Quran, baik surah-surah pendek maupun secara keseluruhan. Hafalan ini kemudian ditindaklanjuti dengan sistem setoran. laitu, membacakan (tasmi) apa yang sudah dihafal di depan Kyai/Ustad.

\section{2) Metod Mengajar Kitab Turath di KUPU SB}

Setelah melihat berbagai-bagai metod yang digunapakai di berbagai sekolah, madrasah, pondok pesantren dan di tempattempat pengajian lainnya. Metod Pengajaran Kitab Turath Melayu di KUPUS SB yang dipandang dapat membantu para pensyarah dalam mengajarkan Kitab Turath agar mahasiswa dengan mudah memahami cara baca, cara menulis dan juga untuk memahami isi teks Kitab-Kitab Turath Melayu ialah:

\section{Talaqqi Kitab:}

1. Setiap pensyarah menerangkan latar belakang kandungan kursus Kitab Turath Melayu yang diajarkan seperti penulis kitab, tujuan mempelajari kitab, isi kandungan kitab dan apa yang diharapkan setelah mempelajari kitab.

2. Setiap mahasiswa diminta untuk membaca dan yang lainnya mendengarkan (menyimak) bacaan temannya dan guru memperhatikan serta memperbaiki bacaan jika terdapat kekeliruan dalam membaca.

3. Menjelaskan maksud bacaan yang sudah dibaca oleh mahasiswa

4. Menghubungkaitkan bacaan yang telah dibaca dengan keilmuan lainnya.

\section{Syarahan:}

1. Setiap pensyarah menjelaskan kandungan kursus Kitab Turath Melayu yang diajarkan seperti penulis kitab, tujuan mempelajari kitab, isi kandungan kitab dan apa yang diharapkan setelah mempelajari kitab.

2. Pensyarah membaca kitab secara langsung dan semua mahasiswa diminta untuk memperhatikan bacaan yang dibaca oleh pensyarah dan diminta mencatat dan memberikan komentar terhadap apa yang disampaikan oleh pensyarahnya dalam kitab mahupun buku catatan.

3. Pensyarah menjelaskan isi kandungan kitab sesuai dengan tajuk yang ada dalam kitab dengan memberikan analisis melalui ilmu-imu lainnya. 


\section{Halaqah:}

1. Setiap pensyarah menerangkan latar belakang kandungan kursus Kitab Turath Melayu yang diajarkan seperti penulis kitab, tujuan mempelajari kitab, isi kandungan kitab dan apa yang diharapkan setelah mempelajari kitab.

2. Pensyarah membahagi mahasiswa ke dalam beberapa kumpulan dengan menyediakan tajuk-tajuk kitab yang terdapat dalam isi kandungan kitab.

3. Pensyarah meminta setiap kumpulan untuk melakukan;

1. Membuatkan ringkasan terhadap tajuk yang diberikan;

2. Mencari dan mengeluarkan ayat-ayat al-Qur'an, hadith-hadith Nabi dan juga qaul Ulama'.

3. Menyalin semula ayat al-Qur'an dengan mencatit nama surah, nombor surah dan nombor ayat.

4. Mentakhrij Hadith secara sederhana

5. Mengenalpasti aqwâl dan kefahaman Ulama' dari teks kitab

\section{Kesimpulan}

Dari beberapa uraian di atas dapat diambil kesimpulan bahawa Pengajaran Kitab Turats Melayu di Brunei Darussalam dapat dilihat dalam beberapa tahapan iaitu tahapan pertama saat IPT Islam masih berupa Maktab pengajian kitab turath Melayu masih terbatas pada para pelajar Maktab sahaja. Kedua, ketika IPT Islam sudah berkembang menjadi Kolej Perguruan, sudah mulai dikembangkan pola dan sistem berbeza. Kitab-kitab yang dijadikan rujukan juga sudah lebih banyak dan beragam, namun bidang-bidang kajian masih terhad pada tiga (3) bidang keilmuan sahaja iaitu bidang Aqidah Islamiyah, Feqh dan akhlak al-tasawur.
Pada masa Kolej ini selain diwajibkan bagi seluruh pelajar Kolej, juga kelas dibukakan bagi kalangan orang awam iaitu pada hari Jumat dan ahad dengan mengkaji empat (4) buah kitab dengan tiga (3) tajuk utama (aqidah, feqh dan tasawuf).

Perkembangan terakhir, pengajianpengajian kitab turath di Negara Brunei Darussalam tidak hanya terhad pada kampus, namun sudah pula diajarkan di masjid-masjid Brunei Darussalam. Pengajian-pengajin kitab yang tersebar di masjid-masjid juga masih berada pada bidang kajian aqidah, feqh dan tasawuf yang berhaluan ahlussunnah wal Jama'ah ala Mazhabil Imam al-Syafi'i sebagai mazhab rasmi Negara Brunei Darussalam.

\section{Daftar Pustaka}

Ahmad bin Ruslan. (1404H/1984). Matn alZubad fi IIm Feqh 'Ala Mazhab Imam al-Syafii. Makkah al-Mukarramah: Maktabah al-Tsaqafah.

Al-Ghazali. (1433/212). Ayyuhal Walad Fi Nashihat al-Muallimin wa Mauidzatihim li ya'lamu wa Yumayyizu 'IIman Nafian min Ghairihi. Mishr: Daar al-Kutub Islamiyyah.

Al-Imam Ibn Hajar al-Atsqalani. (1301H). Manakib As Syaafi'.Mishr:al-Amirah.

Abu Nuaim al-Ashbahani.(1988).Hilyatul Auliya wa Thabaqat al-Asyfiya'.9/3. Mesir: Daar al-Fikr.

Al-Syaikh Daud ibn 'Abdullah al-Fatani. (t.th). Al-Dur al-Thamin. Thailand: Mathba'ah bin Halabi.

Hasan Hanafi, Al-Turâts, $\quad$ wa $\quad$ al-Tajdîd Mauqifunâ mi al-Turâts al-Qadîm, AlMu'assasah al-Jâmi'ìyyah li al-Dirâsât wa al-Nasyr wa al-Tauzi', cet V, 2002.

Ibnu Rajab al-Hanbali.(1425/2005). Dzail Thabaqaat Hanabilah.2/53. Riyadl: Maktabah Abikan. 
AL-Fikra: Jurnal Ilmiah Keislaman, Vol. 15, No. 1 , Januari - Juni 2016

Imam Syamss al-Din az-Zahabi. (2006).Siyar A'laamin Nubala. Jilid:5. Mesir: Daar al-Fikr.

Imam al-Din az-Zahabi. (2006). Siyar A'laamin Nubalaa. Juz:8. Hal.409. Mesir: Daar al-Fikr.

Syauqi Dhaif (2011). Al-Mujam Al-Wasith (المعجم الوسيط). Mesir: Maktabah Shurouq ad Dauliyyah.

Sayyid Syarif 'Abdullah ibn 'Alawi. (t.th). Risâlah al-Muâwanah wa alMuzâharah wa al-Muwâzarah li alRâghibîn Min al-Mukminîn fí Sulûki Tharìq al-'̄kkhrati. Jakarta: AlHaramayn.

Mahyuddin Hj Yahya, 2001. Latar belakang Perkembangan Keilmuan Islam: Dengan Tumpuan Khusus kepada Penulisan Kitab/Manuskrip Jawi di Nusantara. Brunei Darussalam: Jabatan Mufti Kerajaan.

Muhammad Thib ibn Mas'ud al-Banjârî. (t.th). Miftâhul Jannah. Thailand:Mathba'ah bin Halabi.

Pehin Jawatan Luar Pekerma Raja dato Seri Utama DR Ustaz Haji MD. Zain Haji Serudin. (1998). Melayu Islam Beraja Suatu Pendekatan. Brunei Darussalam : Dewan Bahasa dan Pustaka Brunei.

Wahyudi (2013). Pengertian Turâts dan Pembaharuan; Perspektif Hasan Hanafi. Al-Muflihun. com 